\title{
Taking a leap towards a real world macroeconomics teaching
}

\author{
Stefanos Ioannou* \\ Postdoctoral Research Associate in Finance and Geography, \\ School of Geography and the Environment, \\ University of Oxford, South Parks Road, Oxford OX1 3QY \\ stefanos.ioannou@ouce.ox.ac.uk \\ * corresponding author \\ Olivia Bullio Mattos \\ Assistant Professor of Economics, \\ Department of Economics, History, and Political Science, \\ St. Francis College \\ 180 Remsen Street, 11201, Brooklyn, NY. \\ obulliomattos@sfc.edu
}

\begin{abstract}
Despite the centrality of finance in the workings of the modern capitalist economy, macroeconomics is still taught with no serious consideration of monetary and financial dynamics. This has become even more puzzling in the light of the recent financial crisis. Our paper discusses a more pluralistic framework for teaching basic macroeconomics, inclusive of some of the most important ideas of Keynes on interest and money. The incorporation of Keynesian economics not only allows students to broaden their thinking in considering alternative answers to given questions; it also re-shapes the questions themselves. In doing so, it changes the framework within which students come to think of policy. Focusing on the case of monetary policy, we point out the commonality between the mainstream teaching paradigm and the actual mind-set that influences policy making. Furthermore, we discuss the ways in which the scope and aims of monetary policy are altered under a Keynesian/Minskyan framework.
\end{abstract}

Key Words: economic pedagogy, macroeconomics, money, finance, financial crisis, general equilibrium model, Keynesian economics, monetary policy, central bank, endogenous money, financial fragility.

Biographical Notes: Stefanos Ioannou obtained his $\mathrm{PhD}$ in Economics from the University of Leeds in 2016. Prior to his doctoral studies he completed an MPhil in Economics at the University of Athens (2012) and an MSc in Finance at Newcastle University (2009). His research interests include fiscal and monetary policy, financial macroeconomics, financial geography, political economy, and economic pedagogy. He has an extensive experience in applied econometrics and economic modelling. Stefanos has lectured in Economics (University College Cork, 2016-2017), teaching advanced macroeconomics and finance. He is currently involved in the research project 'Cities in Global Financial Networks: Finance and Development in the 21st Century' at the University of Oxford.

Olivia Bullio Mattos obtained her $\mathrm{PhD}$ in Economics from Universidade Estadual de Campinas (UNICAMP), Campinas, SP, Brazil in 2015. She has a MA in Political Economy 
from Pontificia Universidade Catolica de Sao Paulo (PUC/SP), Sao Paulo, SP, Brazil (2010) and a BA in Economics from Faculdades de Campinas (FACAMP), Campinas, SP, Brazil (2006). Her research interests include money, monetary theory, monetary policy, central banking, endogenous money creation, shadow banking, Post-Keynesian and Minskian economics, political economy, Brazilian economy, public banks, and pluralism in economics education. Olivia is currently Assistant Professor of Economics at St. Francis College, Brooklyn, NY.

\section{Acknowledgments:}

We are grateful to our students who have helped us become better teachers. We also want to thank our colleagues at the University College Cork for giving us valuable space for developing pluralistic teaching and for sharing their thoughts and experiences. Individuals who deserve special thanks include Claudia Trevisan, Eleanor Doyle and Gary Dymski. An additional note of gratitude goes to Victoria Chick for encouraging the writing of this paper. We also thank two anonymous referees for their fruitful comments on earlier drafts. The paper has benefited from funding from the European Research Council (European Union's Horizon 2020 research and innovation programme; grant agreement No. 681337). The article reflects only the authors' views and the European Research Council is not responsible for any use that may be made of the information it contains.

\section{Introduction}

A great paradox exists in how macroeconomics is currently taught. While most economists agree that finance is so central to the workings of modern capitalism that it cannot be separated from the rest of the economy, macroeconomics is still taught without any serious consideration of monetary and financial dynamics. This is largely explained by the underlying assumptions of neoclassical macroeconomics. Even in the aftermath of the recent crisis, the neoclassical model is still anchored by money neutrality and the assumption of long-run stability, while the loanable funds theory still underpins the content of standard macroeconomic textbooks. While the recent crisis revived the interest of mainstream scholars on the inadequacy of how macroeconomics is taught, very little change has been enacted in either textbooks or the more broader academic curricula.

In this paper we (briefly) critically outline the basic neoclassical macroeconomic theory as taught at a beginner to intermediate level. In addition, we show how some of the most essential aspects of Keynes' theory can be taught comprehensibly to students of that level. ${ }^{1}$ We focus in particular on the Keynesian view on interest and money, highlighting the role of uncertainty and expectations. We also stress the different views of the two theories over the role of savings, and introduce the implications of bank financing.

We argue that consideration of Keynes' theory is crucial for four reasons:

\footnotetext{
${ }^{1}$ While confusion persists over the question of what is Keynesian and what is not, in this paper we use the term to denote what we believe relates to the actual theory of Keynes; thus, our use of the term is closely aligned to Post- Keynesian economics.
} 
- Presenting new ideas to students, vis-à-vis what is usually found in textbooks; most notably, referring to the different treatments of time, uncertainty and expectations. ${ }^{2}$

- Broadening students' horizons, not only by providing different answers to the questions posed by neoclassical economists, but also by opening the space for considering questions not conceived by the latter. The issue of financial instability, for example, requires a theoretical starting point inclusive of such consideration.

- Establishing the necessary ground for the teaching of more advanced topics on money and finance (e.g., shadow banking). Notice here that the challenge for pluralistic teaching is not just the introduction of more real-world topics replacing abstract theory. The enrichment of the latter, especially at the early stage of studies, is a pre-condition for the former.

- Allowing students to think differently about public policy and policy goals. The fact that many of our students enter policy making institutions creates is a very tangible thread between the reform of macroeconomic teaching and the quality of life of society.

To elaborate the link between teaching and policy we ground our discussion in monetary policy. We highlight the similarity between the main ideas of the New Monetary Consensus theory and the standard neoclassical macroeconomics taught at an elementary level, and briefly outline the policy goals associated with this framework. Furthermore, we show how central bank objectives are altered under a Keynesian/Minskyan framework. An interesting observation stemming from our discussion is that despite steps taken by central banks, including the Bank of England and the Bundesbank towards non-conventional ideas, the main framework underlying central banking policy remains neoclassical.

The rest of our paper proceeds as follows. Section two outlines the main elements of the standard general equilibrium model. We then examine the debate on how macroeconomic teaching should change, a debate that gained momentum in the aftermath of the crisis; we also record the dearth of substantial change since then. Next, we outline our alternative approach for a pluralistic macroeconomic teaching framework, connecting it with monetary policy. We then conclude.

\section{The Current State of Affairs}

\subsection{Mainstream macroeconomic paradigm and policy}

The basic general equilibrium (GE) model is the simplest form in which neoclassical macroeconomic theory is taught to beginner and intermediate level economics students. Due to its nature as a long-run construct, it is a very useful model for elucidating what mainstream textbooks communicate to students as the abstract normality of the capitalist economy. It also forms the soul of the more advanced, dynamic stochastic general equilibrium (DSGE) model, widely used for policy analysis by central banks and global institutions such as the IMF.

\footnotetext{
${ }^{2}$ Although Keynes distinguishes between short and long-term expectations, the latter is crucial for our basic exposition of his theory. In our paper expectations are long-term.
} 
We outline here some of the main elements of the GE model. Our elaboration is based upon the Mankiw's Principles of Macroeconomics ${ }^{3}$, one of the most widely used macro textbooks around the world. ${ }^{4}$

First, production is a function of available quantities of labour and capital. The equilibrium price of the wage for labour and rent for capital is the outcome of the relevant demand and supply. Say's Law holds so there is no demand consideration over what the firm will have to sell. Under freely operating markets the full employment of both labour and capital is achieved. Implicit as it might be, this is a theory of income distribution as it determines the shares of income for labour and capital that are supposed to be consistent with full employment.

Secondly, what is known as the loanable funds theory is introduced, i.e., savings determines investment. Pedagogically this is done by a simple algebraic manipulation of the standard national income identity. ${ }^{5}$ Then there is a leap, from this manipulation to the causal conclusion that the volume of savings determines investment (this is intellectually illegitimate for the simple reason that nothing close to a proof of the claimed causality is ever offered; an accounting statement in itself is not adequate for establishing a causality). The model then shows savings and investment as the supply and the demand of loanable funds respectively, resulting in the equilibrium real interest rate. This is the closest this model gets to a macrotheory of finance. Savings is treated as a scarce and tangible resource, the question of how investment is financed is answered, and banks are introduced at some point later as financial intermediaries facilitating the channelling of savings to investors (whose raison d'être is to act as institutions capable of promoting efficiency, facilitating information flows, monitoring borrowers, etc.).

Third, fiscal policy is discussed by referencing the crowding-out effect. By means of the previously mentioned national income identity, the textbook shows how expansionary fiscal policy effectively absorbs saving resources that could otherwise be directed towards productive private investment (see footnote 5). Later on, this idea is matched with the Ricardian Equivalence, i.e., fiscal expansion today will make households cut their consumption in expectation of higher future taxes. The GE model is then portrayed as a construct aiming at describing the economy in the long run, therefore justifying any lack of realism that might be spotted in the meanwhile.

Some particularly interesting features are worth discussing. For starters, the GE introduces students to the idea that all markets function in a qualitatively similar way. Effectively, there is nothing in the model that allows for a differentiation between the labour market, the financial

\footnotetext{
${ }^{3}$ Earle et al. (2017) notes that the book has been consistently used by Russell Group universities in the UK for teaching core macro, and has sold over a million copies worldwide; moreover Mankiw's overlapping Principles of Economics occupies a joint market share of $40 \%$ in the US, along with McConnell's Economics Principles textbook (Madsen, 2012).

${ }^{4}$ We are grateful to an anonymous referee and the editor for references to critiques of Mankiw's textbooks: see Birks (2014); and Fullbrook (2009). Mankiw's popularity however only exacerbates what is currently taught in economics departments. In addition, we know of no other popular, introductory macroeconomics textbook that challenges any of Mankiw's long-run conclusions.

${ }^{5}$ In a closed economy $\mathrm{Y}=\mathrm{C}+\mathrm{I}+\mathrm{G}-\mathrm{T}$; where $\mathrm{Y}$ is income, $\mathrm{C}$ is consumption, $\mathrm{I}$ is investment, $\mathrm{G}$ is government expenditure and $\mathrm{T}$ is taxes. For a start, assume a balanced budget such that $\mathrm{I}=\mathrm{Y}-\mathrm{C}$; or $\mathrm{I}=$ $\mathrm{S}$ (since savings $\mathrm{S}$ is the difference between the income and private sector consumption). If one adds the public balance the result is I= S - (G- T), such that an expansionary fiscal policy (wherein G- T>0) reduces investment.
} 
market and say the market for pumpkins. Each has a tangible supply and demand that determines the equilibrium price. Furthermore, all important variables are measured in real terms. Money has no role in any of the above analysis other than being treated as a token for transactions; it is irrelevant in the determination of economic outcomes. Third, full information is assumed available to all market participants in the long run.

These observations are important because they constitute some of the most central principles of mainstream macroeconomics. All three are established as foundational stones upon which one can then build more sophisticated macroeconomic models. Any deviation is usually studied as a short-term phenomenon so that their long-run validity goes unchallenged. For instance, while more advanced variations of the model allow for information asymmetries, the overall availability and existence of the information required for economic decision making is never questioned.

In the flow of teaching based on a typical textbook like Mankiw's, next is the formal introduction of money neutrality, along with the distinction of the short-run real effects of prices and their long run irrelevance. Then the IS/LM model, meant to cover some basic Keynesian considerations such as the fiscal multiplier. The model is always treated as a shortrun construct. In that way it coexists with the broader neoclassical frame of thought, it acknowledges its superiority (since time necessarily drives us to the long run), and allows the mainstream textbook to pretend an element of pluralism. Lastly, some standard super, longrun models, such as the Solow growth model are discussed. In such models the role of savings gains even further importance as a determinant of economic activity while the earlier assumption of a fixed technology is relaxed. Banks are still irrelevant. Open economy considerations are also introduced as extensions of these models.

Simple as it might be, the GE model gives rise to some powerful policy conclusions that are usually carried forward as students advance in their macroeconomic studies:

- Unemployment is explained by wage rigidities, typically identified as a labour market imperfection, caused principally by trade-unions and minimum wage legislation.

- Fiscal austerity is explicitly exposed as a pro-growth policy as it effectively allows for more financial (saving) resources for the private sector. This conclusion can be modified for a short-run horizon, as in the IS/LM model, but its long-run validity goes unchallenged.

- The financial market is sketched as a meeting space for savers and investors. As long as the equilibrium interest rate is achieved (which a free market ensures), and if efficient institutions exist (efficient in intermediating, monitoring and facilitating information flows; the latter crucial for overcoming any existing information asymmetries) nothing can go wrong. In this context, there is no concern about financial instability. In all instances, any episodes of financial bubbles and crises are explained by reference to exogenous shocks disturbing an otherwise self-equilibrating system.

\subsection{Reactions and developments since the crisis of 2007/08}

The recent financial crisis posed a challenge for mainstream teaching. First, it revived a genuine interest in macroeconomics, as there were questions desperately seeking answers, keenly demonstrated by the recent movement urgently calling for more pluralism. ${ }^{6}$ Secondly,

${ }^{6}$ See http://www.rethinkeconomics.org 
it created some discomfort for mainstream economists, who were at pains to provide accurate answers with reference to the material of the textbook (notice that what poses a greater challenge than providing a narrative for the crisis is doing so within the intellectual frame used for teaching, which can often turn into a straighjacket).

In a 2010 symposium on the 'Financial Crisis and the Teaching of Macroeconomics' by the Journal of Economic Education, several scholars, including textbook authors, reflected on the way forward in teaching macroeconomics and finance. Rajan (2010) called for a takeover of mainstream macroeconomics by development economics. From his viewpoint, the crisis showed that the institutions of industrialised economies are not as perfect and complete as assumed at an earlier stage. Shiller (2010) stressed the importance of incorporating psychological insights into macroeconomic teaching, enabling relevant models to gain realism. Blinder (2010) identified a list of finance-related topics that could be added to macroeconomic pedadogy, including multiple interest rates, ${ }^{7}$ asset market bubbles, securitization, leverage, insolvency and illiquidity. Blinder expressed concerns over trade-offs involved in deciding what to include in teaching and what to jettison, as well as in deciding the complexity of an undergraduate discussion of finance. More critically, Friedman (2010) acknowledged the failure of mainstream teaching to account for the real effects of finance. Moreover, he agreed with Minsky in identifying financial institutions not as passive intermediaries, but as separate institutions with their own profit motives, and in pointing out the inherent instability of financial markets. He also criticized Say's Law in assuming demand considerations away, and mentions the importance of distributional considerations. In a more recent paper, Blinder (2015) also called for better teaching of basic Keynesian IS/LM economics (as related for instance with the fiscal multiplier) and acknowledged even more emphatically the value of Minsky's contributions to our understanding of how finance works.

A recent issue of the Oxford Review of Economic Policy (2018) provides a similar set of reflections from some of the most well-known mainstream scholars, including Olivier Blanchard, Simon Wren- Lewis, Wendy Carlin, David Soskice, Joseph Stiglitz and Paul Krugman. Although the focus of these contributions is on the more advanced level of graduate teaching, it is interesting to observe the consensus that emerges amongst the mainstream community ten years after the crisis in how to reform macroeconomics. Vines and Wills (2018) synthesized key points of the relevant articles; they point out a general acknowledgement of the short-comings of the pre-crisis benchark DSGE model and call for necessary modifications. These include the introduction of financial frictions, the relaxation of the assumption of rational expectations, the introduction of heterogeneous agents, and the establishment of what they identify as more appropriate microfoundations (in the sense of explaining endogenously the emergence of certain features of the model which were previously taken as exogenous inputs, e.g., the existence of nominal rigidities). The trade-off between model complexity and pedagogical reach is a challenge that is explicitly recognised in their discussion. Overall, in face of the possibility of modifying the mainstream paradigm along these lines, Vines and Wills state that "[m]ost [of the participants in this issue] agree with our own view, that it can and should be rebuilt rather than abandoned" (2018, p. 17; Stiglitz's paper in the Issue on the other hand is of a more critical flavour, see Stiglitz, 2018).

\subsection{Has anything changed so far?}

\footnotetext{
${ }^{7}$ See Gertler (2013) for an interesting, simplified model for teaching unconventional monetary policy at an undergraduate level.
} 
Naturally, it is interesting to ask how things have changed in practice since the crisis. In two articles Madsen $(2012,2013)$ provides some answers by reviewing the actual changes in some of the best-selling US textbooks. A main finding is that most textbook authors have indeed been claiming major breakthroughs for their most recent editions, which unfortunately are hardly visible. Accordingly, some positive evidence exists when textbooks are examined as a group, including the introduction of new theoretical concepts (e.g., default risk) and the revision of some older ones (e.g., lemon problem). However, they are not accompanied by any substantial change in economic theory. In addition, any discussion that could potentially pose a challenge to neoclassical thinking is usually found in prefaces or in separate boxes and sections. If anything, the financial crisis is mainly handled in descriptive terms, as an appendix to what was previously taught.

This discussion is important for one more reason. As pointed out by Madsen, it shows that the correct question is not whether textbooks have changed since the crisis, but rather how have they changed. There is a clear difference between textbook updates, where new chapters and real world examples are added as appendices to existing material (something which usually happens either way for marketing and selling purposes), and paradigm shifts where new theories are introduced, challenging what was previously taught.

\subsection{The Mankiw and Taylor example}

A more recent, concrete example is from Mankiw and Taylor's introductory economics textbook (Mankiw and Taylor, 2017). On the book's back cover the authors claim that "New topics have been added including, for example, Marxist and Feminist theories on labour and the section on central banks re-written to reflect current operations, giving wider context to economic issues...” Peculiar as it might seem, here is one of the world's most popular textbooks appearing to be proud in introducing feminist and Marxist perspectives into their analyses.

Mankiw and Taylor's style of pluralism does not seriously challenge the standard neoclassical material developed in their book. First, the discussion on Marxist and feminist theory is hardly of merit. Suffice here to say that out of a total of 805 pages, the two theories combined occupy 10 pages in total. More interesting is that the discussions on finance and monetary policy have been slightly extended. Although the models and theory taught in the main part of the book remain the same, there is now some brief description of instruments such as collateral debt obligations and credit default swaps (pp. 504-506); a few pages are dedicated in outlining quantitative easing (pp. 566- 568), while basic financial mechanics (e.g., present value discounting, portfolio diversification, etc.) is covered. Deserving additional merit is the brief discussion on some of the causes of the recent financial crisis (chapter 26): a page on deregulation, a few more on the sub-prime market; also introducing some of the relevant terminology, such as securitization and special purpose vehicle (see pp. 537); asset bubbles and Keynes's animal spirits are also mentioned briefly (pp. 542- 546). Furthermore, a few pages are dedicated to Minsky (pp. 547-549), which nonetheless can be highly questioned with respect to the manner in which the relevant theory is presented.

\subsection{Teaching initiatives for pluralism in economics}

Given the gap between the demand for pluralism and its inadequate supply in mainstream economics textbooks, a number of initiatives have recently emerged globally for promoting pluralistic teaching, e.g., Rethinking Economics, the Exploring Economics platform, and the more mainstream Curriculum in Open-access Resources in Economics (CORE) project. 
Despite diversity in operation and in the degree and type of pluralism achieved by each, these initiatives have set the stage for collaboration between students and academics. They also provide valuable learning resources, including brief outlines of different schools of thought, essential references for each school, as well as new learning material.

Such projects constitute significant steps forward. First, in their function as networks they bring together people who might otherwise find themselves isolated within the walls of mainstream departments. In addition, alternative teaching material can greatly help academics interested in pluralistic teaching, people who would otherwise need to spend a significant amount of time in cherry-picking and putting together various resources by themselves (which is even more beneficial than what it ostensibly seems, given the substantial amount of time required by academics for pushing forward their research agendas).

\subsection{Developments across economic departments}

In the broader picture, it is also interesting to ask whether any space has opened up at a departmental level for the teaching of non-neoclassical theories. Focusing on the UK, Earle et al. (2017) show how minimal any change has been so far (see particularly chapters 2 and 3). By reviewing the curricula of seven Russell Group universities, ${ }^{8}$ Earle and his colleagues illustrate neoclassical dominance. Striped from any critical thinking, neoclassical economics is still taught as economics, mainly training students how to solve mathematical puzzles rather than engaging with any policy-related issues:

"Neoclassical economics [...] underpinned almost every model taught in every module in our curriculum review. Teaching this perspective as if it is economics allows economists to see their discipline as a complete system, and imbues them with the idea that neoclassical economics can and should be used to understand any problem that they face” (Earle et al., 2017, p. 40).

As their evidence suggests, out of a total of 172 module outlines, only seventeen modules and two core modules discuss non-neoclassical perspectives. Most are optional, clustered in the final year. Moreover, if one was to put aside history of economic thought modules, three out of the seven departments reviewed have no mention of any alternative perspectives in their syllabus at all (see Earle et al., 2017, p. 61).

\section{An Alternative Paradigm for Macro Pedagogy and Policy}

Having outlined the current state of affairs in the teaching of macroeconomics, we now reflect over the possibilities for an alternative way of organizing a beginner to intermediate level macroeconomics course. Our aim is to sketch a framework that is simple enough to teach to students, while also adequately highlighting the centrality of finance and money, and for generating real-world policy proposals.

Being junior academics ourselves we have acquired a first hand experience of the difficulties involved in teaching topics 'outside the box'. Before engaging into teaching one might think that the only thing to attract students' interest is teaching them the 'good stuff'. Just because

\footnotetext{
${ }^{8}$ These include the London School of Economics; the Universities of Sheffield, Exeter, Cambridge, Glasgow and Manchester; and Queen's University Belfast.
} 
we keenly studied Marx, Keynes, financial crises, economic history, political philosophy, etc., we might assume that students will share our passion. Not at all. As pointed out by Kinsella (2010), introducing students to alternative theories without creating confusion in the class requires great care.

Focusing on basic macroeconomics is important because at this stage the crucial framework for thinking is set; the framework in which students are to conceptualise the more advanced topics taught later on. Thus, pluralism in introductory macroeconomics is a necessary condition for pluralism in more advanced macro topics and models, and effectively for pluralism in the realm of policy. No matter how qualified a pedagogue might be, issues discussed in year 3 will usually be processed through the perceptual lenses established in year 1.

From a broader perspective, critical engagement with different theories, the questioning of their assumptions, and the link of such theories with broader political and philosophical topics can make macroeconomics particularly intriguing. This however is not something to be saved as a surprise for final year students. As pointed out in Varoufakis (1998, p. xi) "[i]f we leave these controversies aside 'for a while', there is a danger we will never come back to them, either because we will have forgotten them, or because the more thoughtful students who detest being treated like children may abandon us and our discipline too early.”

We propose a teaching approach for contrasting some of the most important aspects of Keynesian economics with their neoclassical counterparts. These include the issues of: how investment is determined; ii) how it is affected by the interest rate; iii) how the latter is determined in the money market; and iv) how investment is financed. While the flow of themes is our own choice of how to organize relevant material, our illustration of the Keynesian theory is facilitated by Victoria Chick's 'Macroeconomics after Keynes' (Chick, 1983). Illustrated briefly, our approach is as follows:

i. Determinants of investment: The introduction of effective demand-a concept fundamentally different from aggregate demand-is particularly useful not only for challenging Say's Law but also for allowing students to make sense of how time is treated differently in the two theories. Effective demand describes firms' decisions to invest today based on their expectations of future demand for their output. These expectations play a crucial role in determining the current level of employment.

ii. Other than the fact that Keynes focuses on the nominal rather than the real interest rate, there is partial agreement with neoclassical theory that, all else equal, a lower interest rate should positively affect investment. The fundamental difference is the interplay Keynes allows between interest rate fluctuations and firms' expectations. The interest rate itself is half of the story. The state of expectations forms the other half, implying that a lower interest rate, for example, might fail to deliver a higher volume of investment if accompanied by pessimistic expectations. ${ }^{9}$

\footnotetext{
${ }^{9}$ Keynes' method for analytically communicating this point is his concept of the marginal efficiency of capital (MEC). In deciding how much to focus on the MEC, an inherent trade-off exists between teaching difficulty and depth: the MEC is a necessary tool for understanding Keynes, but is at the same time one of his more confusing terms. Its confusing nature is also highlighted by Chick (1983, p. 131, footnote 7).
} 
iii. The analysis of the demand and the supply of money. There are two notable differences: first, the demand for money in Keynes is fundamentally underpinned by psychological factors. What makes money unique is its perception as the most liquid, and thus safest asset. As such, money is demanded as an end in itself, with real effects on the economy. Following, the interest rate for Keynes is not a product of the demand and the supply of funds (investment and savings respectively) as suggested in the loanable funds theory. As long as psychological factors relevantly explain the demand for money, they also determine the prevailing rate of interest.

iv. The role of savings: in the Keynesian theory savings appears as a residual, being equal to investment only ex post. It is investment which at the first place gives rise to income, and therefore allows for a part of income to be saved. The natural question that arises here is how investment is financed, if not by savings. Two distinctions need to be highlighted: first, the difference between direct and indirect lending, and secondly the distinction between the primary and the secondary financial market. Direct lending (e.g., bonds and equity) means that some savings can be channelled towards firms. Even here, however, the distinction between a primary and a secondary market implies that there is no obvious reason why savings has to finance new investment (i.e., flow towards the primary market). On the other hand, the existence of indirect lending (i.e. banks) means that direct lending is not the sole way of acquiring funds. It is exactly this form of lending that permits the reversal of the neoclassical S equals I identity. In a modern capitalist economy, investment financing can be generated by banks ex nihilo.

In replacing savings with finance we come full circle. Moreover, by the time finance enters into our macroeconomic analysis, the theories of endogenous money and endogenous financial instability, consistently put forward by Keynesian and Minskyan authors become relevant. These are crucial for policy and are discussed in the following section.

\section{Implications for monetary policy}

Presenting students with two different macroeconomic theories helps them grasp different views on policymaking. At the same time, the joint consideration of macroeconomics and finance allows for a broader spectrum of policy goals. To illustrate we focus here on the example of monetary policy and students' perception of how central banking should work.

The school of thought behind most central bank policymaking before the subprime crisis, especially during the Great Moderation was the New Monetary Consensus (NMC). This school was established during the 1990s with the merger of the New Classical and New Keynesian schools, both deeply rooted in the GE theory and the DSGE model. Given that most central bankers in developed countries were educated in mainstream universities, NMC provided the framework within which they learned economics and came to think of policy.

In essence, the underlying philosophy of the NMC isn't different to the neoclassical GE and the IS/LM economics. Albeit more sophisticated in terms of the maths, NMC's two pillars perform a very similar role. On one hand, the New Classical insights offers the long-term vision of the model: this school was greatly influenced by monetarism, which resuscitated the Quantity Theory of Money (QTM) during the 1970s- money neutrality holds full strength, savings is the ultimate source of investment funds, while the economy is assumed inherently stable and supply led. On the other hand, the New Keynesian pillar offers some insights to 
make the NMC model more applicable to the real world, e.g., the incorporation of price and wage rigidities. Always such considerations are treated as short-tun phenomena, hence, maintaining the over-arching validity of the New Classical theory. In addition, banks are consistently treated as passive financial intermediaries between saving and investment, without influencing economic outcomes. ${ }^{10}$ Bizarre as it might sound, central banks often designed monetary policy based on models that include no banking sector whatsoever, e.g., Smets and Wouters (2002) concerning the ECB.

Overall, the most noteworthy proposals emanating from the NMC are: the identification of low inflation as the main (and preferably only) goal for monetary policy; a rule-based framework (e.g., Taylor Rule) for policy makers; the promotion of greater transparency and communication; and the independence of the central bank from the elected government. All these doctrines were widely adopted by many central banks, including the Federal Reserve, the ECB, and the Bank of England. Moreover, consistent with mainstream macroeconomics, and in contrast with the consideration of price stability, financial stability never was identified as a policy target.

This ideology was strong amongst academics and central bankers and, along with optimism of the Great Moderation, led neoclassical economists to believe in the accuracy of their models and their macroeconomic pedagogy. As Robert Lucas himself said in 2003, "My thesis in this lecture is that macroeconomics in this original sense has succeeded: its central problem of depression prevention has been solved, for all practical purposes, and has in fact been solved for many decades” (Lucas, 2003, p. 1).

Nonetheless, the crisis showed that despite their ostensible elimination, risks and fragility were present, obscured in the complexity of modern money and finance. After the crisis, the unconventional measures implemented by several central banks (including the Federal Reserve, the Bank of England, the Bank of Japan, and the ECB) returned the recent economic debate to the links between monetary policy, finance, and money creation. As Janet Yellen, chair of the Federal Reserve from 2014-2018, said in a 2015 speech:

"The global financial crisis had profound effects on our economy, and it altered the way many think about monetary policy. At the peak of the crisis and during its immediate aftermath, unconventional monetary policy measures were designed and implemented by the Federal Reserve and other Central Banks around the world. Moreover, policymakers should be mindful of new channels for monetary policy transmission that may have emerged from the intricate economic and financial linkages in our global economy that were revealed by the crisis. Finally, it is crucial to understand the effect of regulations and possible changes in financial intermediation on monetary policy implementation and transmission” (Yellen, 2015, emphasis added).

Albeit this shift in monetary policy, however, and despite some interesting developments in the research conducted by central banks (see below), the broader conceptual framework of central bankers has changed very little. The idea, in particular, that the recent crisis was the result of external shocks and fraudulent behavior, and not the outcome of an inherent unstable financial system still underlines the thinking of policy makers. Outlined briefly, today's approach of central banks to monetary policy has been Quantitative Easing (QE), initially

${ }^{10}$ For a more in- depth outline and critique of the NMC see Arestis, 2010; Pilkington, 2013. 
designed as a short-term measure for restoring liquidity in key financial markets, such as the commercial paper market, repo market, etc. Nonetheless, QE policy soon turned into a longerterm measure for re-boosting economic growth, an expectation with clear monetarist roots: simply put, the idea was that money injected to banks would find its way towards the real economy and would eventually lead to a higher inflation rate. The Federal Reserve, expanded its balance sheet from around US\$ 900 billion in 2007 to more than US\$ 4.5 trillion in 2016 (Fed data). Instead of reaching the real economy however, the Fed-created liquidity has mostly been maintained by banks as idle reserves. As a result, economic growth has remained at anemic levels, at least compared with the pre-crisis growth rates, while inflation has been consistently below the $2 \%$ benchmark.

It is crucial to move beyond the mechanistic understanding of the economy, the treatment of banks as intermediaries and the identification of savings as the source of investment funds. Consistent with our earlier exposition of the Keynesian theory, the role of expectations and uncertainty must become central to appreciate the scope and limitations of monetary policy.

Most importantly, the ability of banks to create money to finance investment and other expenditures independently of savings needs to be emphasized: whenever a bank issues a loan (an asset for the bank) it credits an account (a liability for the bank) with an equivalent sum of money. As with any liability, a bank account is essentially a promise from the bank to the account holder: a promise to convert bank account money into cash at any point of time. In order to fulfil its promise when needed, the bank does not need to hold any savings in advance. Only after providing credit it needs to acquire access to liquid resources. The reserve funds offered by the central bank serve exactly that end; it is through the latter that a central bank comes to exercise monetary policy in the first place. Thus, the role of the central bank is not to determine the volume of money in circulation (which is endogenously determined by banks when providing credit), but to set the cost of reserves and thereby allow banks to perform their role. ${ }^{11}$ Only indirectly, through the interest rate set on reserves can a central bank influence the creation of money (for two very good pedagogical references on endogenous money see Fontana, 2009; Tymoigne, 2016). ${ }^{12}$

In addition, reform of monetary thinking must recognize that as the economic cycle advances, economic units tend to take riskier financial positions, increasing their leverage and, as a consequence the financial fragility of the economy (for a brief overview see Minsky, 1992).

${ }^{11}$ Banks' capacity to create money is also acknowledged by neoclassical and New Keynesian economists, done through the process of the deposit multiplier (known as exogenous money model) where banks create money based on the pre-existing stock of deposits and the high powered money created by the central banks. Furthermore, some post-Keynesians, such as Lavoie (2014), argue that since modern NMC models advocate that the central bank controls the short-term interest rate and not the quantity of high-powered money (after a failed attempt by the Federal Reserve to control the quantity of money in the beginning of the 1980s), there exists an implicit acceptance of the endogeneity of money. Overall however, there are still notable differences between the endogenous money theory and the mainstream view since the two stem from completely different assumptions. First, the NMC's ex-ante existence of deposits and high-powered money is at odds with the endogenous money view which takes both as ex-post outcomes of the money creation process. Secondly, mainstream economists do not incorporate the interactions between the banks and the rest of the economy as the process that drives money creation, being at the same time a force that pushes growth but also creates financial instability.

${ }^{12}$ Pedagogically, this relatively simple illustration of endogenous money theory is also crucial for teaching more advanced topics on money and monetary policy, such as the shadow banking system from a Keynesian/Minskyan perspective (e.g., Gabor and Vestergaard, 2016). 
First, the detachment of credit creation from the available savings implies that from a technical point of view banks have no limitation in expanding credit. Secondly, under a euphoric business climate borrowers and lenders are more comfortable with increasing debt, which might otherwise be unsustainable compared to income flows of these borrowers; expectations of such flows might turn out to be over-optimistic. Equally, euphoria can lead to the lowering of creditworthiness standards, and hence the expansion of credit to previously redlined borrowers. Eventually, "good" times lead to excessive risk taking by both lenders and borrowers, and thus pave the ground for fragile balance sheets. As Minsky's most famous quote goes: stability is destabilizing (Minsky, 1986).

In this context, a central bank has two crucial functions for maintaining a stable financial system: first, engage a monetary policy that brings money and credit close to levels compatible with financial stability; and secondly, establish a coherent regulatory framework for preventing unsustainable and predatory banking practices. In the former, central bankers need to understand their placement within the broader financial system: while able to influence money creation, they do not create money. In the latter they need to be aware of banks' continuous incentives to circumvent regulation by means of financial innovation. In that regard, what is needed is not a passive, rule-based framework, but an active and evolving financial regulation. A prerequisite for the performance of both functions is the departure from the equilibrium model, and the replacement of rational and calculable expectations with fundamental uncertainty. It is within the latter that monetary policy unfolds (Aglietta, 2008).

To be fair, some central banks have gradually come closer to accepting the idea of endogenous money long proclaimed by Keynesian and Minskyan economists. One example includes a report by the Bank of England in 2014, in which authors corroborated endogenously created money, explaining how commercial banks create money simply "with a 'stroke of bankers' pens when they approve loans" (McLeay, Radia and Thomas, 2014, p. 16). Another similar example is from a recent (April, 2017) article by Deutsche Bundesbank in which the authors claim that "the majority of the money supply is made up of book money, which is created through transactions between banks and domestic customers" (Deutsche Bundesbank, 2017). Furthermore, financial fragility has recently gained some attention, with aspects of it modelled in DSGE models e.g., Kumhof and Ranciere (2010). Nonetheless, such developments are still contained in working papers and staff reports, without any evident effect on applied monetary policy yet.

\section{Conclusions}

Paradoxically, after the most recent crisis mainstream macroeconomics is still without any serious consideration of finance. This is despite the evident centrality of the latter in the workings of modern capitalism, and despite the ground-shaking events that followed the crisis. Just as before, the economic system is portrayed as inherently stable; money is discussed as a veil, and banks are considered as intermediaries with no impact of their own upon the real economy.

To bridge the gap, a more pluralistic teaching framework, inclusive of Keynesian economics is offered. The introduction of the Keynesian view, in addition to allowing students to broaden their thinking by considering the different answers these theories offer to given questions also enables them to expand their thinking towards issues otherwise ignored. The issue of financial 
instability, which at the first place requires a theory capable of including it as a consideration, is the most indicative. In addition, it enables the teaching of more advanced topics in macro and finance. Furthermore, it enables students to think differently about public policy and policy goals.

\section{References}

Aglietta, M. (2008) 'Macroéconomie Financière’, La Dévouverte, Paris.

Arestis, P. (2010) 'The New Consensus in Macroeconomics: A Critical Appraisal', in Fontana and Setterfield (Eds.), 'Macroeconomic Theory and Macroeconomic Pedagogy', Palgrave Macmillan, New York.

Birks, S. (2014) 'Textbook Commentaries Project. Mankiw’s $7^{\text {th }}$ Edition', World Economics Association, https://www.worldeconomicsassociation.org/textbook-commentaries/ (Accessed 15 June 2018).

Blinder, A. (2010) 'Teaching Macro Principles after the Financial Crisis', The Journal of Economic Education, Vol. 41, No. 4, pp. 385- 390.

Blinder, A. (2015) 'What Did We Learn from the Financial Crisis, the Great Recession, and the Pathetic Recovery?', The Journal of Economic Education, Vol. 46, No. 4, pp. 135- 149.

Chick, V. (1983) Macroeconomics after Keynes. A Reconsideration of the General Theory, Philip Allan Publishers, Oxford.

Deutsche Bundesbank (2017) 'How Money is Created', https://www.bundesbank.de/Redaktion/EN/Topics/2017/2017_04_25_how_money_is_create d.html (Accessed 27 August 2017).

Earle, J., Moran, C., and Ward-Perkins, Z. (2017) The Econocracy. The Perils of Leaving Economics to Experts, Manchester University Press, Manchester.

Fontana, G. (2009) Money, Uncertainty and Time, Routledge, London.

Friedman, B. (2010) 'Reconstructing Economics in Light of the 2007-? Financial Crisis', The Journal of Economic Education, Vol. 41, No. 4, pp. 391- 397.

Fullbrook, E. (2009) 'The meltdown and economics textbooks,' in Reardon, J. (Ed.) The Handbook of Pluralist Economics Education, Routledge, London, pp. 17-23.

Gabor, D. and Vestergaard, J. (2016) 'Towards a theory of shadow money', INET Research Paper,https://www.ineteconomics.org/uploads/papers/Towards_Theory_Shadow_Money_GV _INET.pdf (Accessed 3 February 2018).

Gertler, M. (2013) 'Monetary Policy After August 2007', The Journal of Economic Education, Vol. 44, No. 4, pp. 329- 338. 
Keynes, J. M. (1973[1936]) The General Theory of Employment, Interest and Money, Cambridge University Press, Cambridge.

Kinsella, S. (2010) 'Pedagogical Approaches to Theories of Endogenous versus Exogenous Money’, International Journal of Pluralism and Economic Education, Vol. 1, No. 3, pp. 276282.

Kumhof, M. and Ranciere, R. (2010) 'Inequality, Leverage and Crises', IMF Working Paper, WP/10/268, https://www.imf.org/external/pubs/ft/wp/2010/wp10268.pdf (Accessed 15 August 2017).

Lavoie, M. (2014) Post Keynesian Economics: New Foundations, Edward Elgar, Cheltenham, UK.

Lucas, Jr. R. E. (2003) 'Macroeconomic Priorities', Presidential Address, One-hundred fifteenth meeting of the American Economic Association, Washington, DC, January $4^{\text {th }}$.

Madsen, P. (2012) 'Principles of Economics Textbooks: Lessons to be Learned in Light of the Financial Crisis', International Journal of Pluralism and Economic Education, Vol. 3, No. 2, pp. 240- 250.

Madsen, P. (2013) 'The Financial Crisis and Principles of Economics Textbooks', The Journal of Economic Education, Vol. 44, No. 3, pp. 197- 216.

Mankiw, G. (2010) Macroeconomics, $7^{\text {th }}$ edition, Worth Publishers, New York.

Mankiw, G. and Taylor, M. (2017) Economics, Cengage Learning, $4^{\text {th }}$ edition.

McLeay, M., Radia, A. and Thomas, R. (2014) 'Money creation in the modern economy', Bank of England Quarterly Bulletin, Vol. 54, No. 1, Q1.

Minsky, H. (1986) Stabilizing an Unstable Economy, Yale University Press, New Haven, Connecticut.

Minsky, H. (1992) 'The Financial Instability Hypothesis', Working Paper no. 74, The Jerome Levy Economics Institute, Annandale-on-Hudson, N.Y.

Pilkington, M. (2013) The Global Financial Crisis amd the New Monetary Consensus, Routledge, New York.

Rajan, R. (2010) 'The Financial Crisis and the Death (or Hegemony) of Development Economics, The Journal of Economic Education, Vol. 41, No. 4, pp. 398- 402.

Shiller, R. (2010) 'How Should the Financial Crisis Change How We Teach Economics?', The Journal of Economic Education, Vol. 41, No. 4, pp. 403- 409.

Smets, F. and Wouters, R. (2002) 'An Estimated Stochastic Dynamic General Equilibrium Model of the Euro Area', ECB Working Paper Series, Working Paper No. 171, https://www.ecb.europa.eu/pub/pdf/scpwps/ecbwp171.pdf, (Accessed 20 August 2017). 
Stiglitz, J. (2018) 'Where Modern Macroeconomics went Wrong', Oxford Review of Economic Policy, Vol. 34, No. 1- 2, pp. 70- 106.

Tymoigne, E. (2016) The Financial System and the Economy. Principles of Money and Banking, available upon subscription at SCRIBD.

Varoufakis, Y. (1998) Foundations of Economics. A Beginner's Companion', Routledge, London.

Vines, D. and Wills, S. (2018) 'The Rebuilding Macroeconomic Theory Project: an Analytical Assessment', Oxford Review of Economic Policy, Vol. 34, No. 1- 2, pp. 1- 42.

Yellen, J. (2015) 'Welcoming Remarks', Monetary Policy Implementation and Transmission in the Post-Crisis Period, Research conference sponsored by the Board of Governors of the Federal Reserve System, Washington, D.C.: November $12^{\text {th }}$. 